\title{
On Cultivating Undergraduates' Scientific Research Ability in Business English Major
}

\author{
Xiao-si SONG ${ }^{1, a, *}$ \\ ${ }^{1}$ Harbin University of Commerce, Harbin, China, 150028 \\ a12627058@qq.com
}

Keywords: Undergraduates, Scientific Research, Innovation, Business English Major, Cultivation.

\begin{abstract}
Nowadays, the research on the cultivation of Business English undergraduates' scientific research and innovation ability is still in its initial stage. How to explore the suitable model for the cultivation of English undergraduates' scientific research innovation ability is of great urgency for the construction and development of Business English majors in China. Through the analysis of the present situation and causes, this paper explores the significance of cultivating Business English undergraduates' scientific research innovation ability, Analysis, Exploration and Reflections on the Feasibility of Strengthening the Cultivation of Undergraduates' Ability of Scientific Research and Innovation in English Majors.
\end{abstract}

\section{Introduction}

Innovation Spirit and innovation ability has become a new driving force of economic and social development. Under the new situation of building an innovation-oriented country, that cultivating the undergraduates' scientific research ability and innovation spirit is a inevitable requirement of development of knowledge and economy society for the improvement of the quality of higher education talents.

In "A Number of Opinions of Ministry of Education on Further Deepening the Reform of Undergraduate Teaching ", it particular states that the reform should include deepening the reform of undergraduate education, actively promoting the training mode of innovative talents, comprehensively strengthening the quality and ability of undergraduate training, upholding the knowledge, ability and quality, developing students' ability to innovate, to carry out social survey, social practice, to participate in scientific research and to carry out innovative experiments and practice, enhancing the students' innovative spirit and innovative ability, achieving the goal of more attention to the ability and quality[1]. And therefore in order to meet undergraduate academic standards for the business English major, it should be targeted to strengthen the business English undergraduate scientific research ability training and comprehensively improve their overall quality.

\section{The Importance of Constructing Scientific Research Ability Training System for Undergraduates in Chinese Universities}

Undergraduate research capacity training is an inevitable choice that to reform the traditional education model is to adapt to society's new demand for talents. University is a high-level education and its trained talents should not only have a more solid basic knowledge and expertise but also should have a certain degree of scientific research ability. For a long time, in China only masters and doctors participate in scientific 
research activities, while undergraduate learning is limited to book knowledge and basic experimental class. In this kind of education, talents tend to be the accumulation type, and less creative type. The talent's quality lags behind the needs of socio-economic development. To reform the traditional mode of education, universities should train more original, innovative and creative talents and reform the teaching method.

Undergraduate research capacity training is an important way to train innovative talents and to improve the quality of education. With the deepening of higher education reform, the strategic objectives and priorities of higher education have shifted to how to cultivate innovative talents. The core of innovative talent cultivation is quality cultivation. There are many channels, one of which is the cultivation of scientific research ability. It is beneficial to fully play the university's advantages in intelligence resources and scientific research, to build a new educational platform based on students' participation in research, to promote the cultivation of innovative talents in an all-round way, and to help students understand and feel the science in the whole process of research, deepen the understanding of the existing knowledge, expand knowledge, the establishment of a reasonable knowledge structure, and to train students practical innovation ability, social adaptability, teamwork ability, cultivate rigorous and realistic scientific style, for students in the future Scientific research or innovative work.

\section{The Necessity of the Cultivation of Scientific Research Abilities of Business English Majors}

To cultivate students 'preliminary scientific research ability is the proper meaning of undergraduate education. In particular, the cultivation of undergraduates' scientific research ability and standardizing their training mode have become an important goal of higher education reform.

\section{One of the Objectives of Business English Undergraduate Teaching.}

"Higher Education Law" stipulates that: "Undergraduate education should enable students to more systematic grasp the discipline, the necessary professional theory, basic knowledge, to master the necessary basic skills, methods and related knowledge, and to have the ability to engage in the professional work and research".

\section{An Important Part of Business English Undergraduate Teaching Reform.}

During the past several years, the whole society's requirement of talents is higher than before. It is one of the important tasks for the country to cultivate talents with innovation spirit and innovation ability. It can be seen that the cultivation of scientific research ability of undergraduates, including business English undergraduates, is the need of creating innovative talents and is an important content of undergraduate teaching reform. Organizing students to carry out scientific research is not only an important way to enhance the capacity of innovation an important way, but also the most critical measure for undergraduates' teaching reform. There are two main options for undergraduate students after graduation, one of which is to continue to graduated degree or doctor degree and the other of which is to get employment. No matter what kind of choice, for undergraduates, having a preliminary research capacity is a good foundation for the future development. Therefore, during the English undergraduate stage, it should be improved the professional quality of students in many ways and create conditions for students further study and employment as much as possible. 


\section{Measures of Strengthening the Cultivation of Scientific Research Ability of Business English Majors}

The cultivation of scientific research and innovation ability of undergraduates involves many aspects of teaching and scientific research. It is a systematic project and should start from various ways and take various measures to obtain the best effect. At present, there are few researches on the cultivation of business English undergraduates' scientific research ability, so it is urgent to explore the suitable model for the cultivation of scientific research ability of English majors in China, especially for the construction and development of English majors in China[2].

\section{Optimizing the Curriculum System}

Optimizing the curriculum system and carrying out the basic scientific research and teaching in the undergraduate course is the key to improve the innovation of scientific research ability of business English[3]. So university should change the teaching concept, optimize the course system, develop teaching related to scientific research and set up course and lecture related to scientific research, which means to combine the quality of scientific research and cultivating of innovating ability with the daily teaching. And according to their own features and advantages, universities could adjust talent training plans, conduct a reform of teaching idea, content and models and improve students' quality of scientific research and cultivating of innovating ability through innovating the course system.

\section{Emphasizing Thesis Writing}

Business English belongs to the category of humanities and social sciences, so scientific research results are more reflected in the writing of the paper. Graduation thesis writing is a very important teaching link in university education. It is a practical learning activity, which is summarized and applied through the systematic study. Therefore, during encouraging English majors to carry out scientific research activities, it is needed to guide them to relate research projects to their graduation thesis. It is a great way to promote the undergraduate scientific research and innovation ability. Students not only can successfully complete the thesis, but also boldly attempt the scientific exploration. It could improve the ability to asking questions, problem-solving skills and oral expression and written expression ability, including basic innovation ability through a systematic exercise and play a positive role in the students' future development.

\section{Strengthening the Construction of the Second Classroom and Emphasizing other Research Methods like Competition}

The second classroom builds a platform on which students could expand their qualities. It is a new carrier of quality education and a new form in which students could participate in scientific and technological activities. Strengthening the construction of the second classroom is an effective means of implementation of innovative education, cultivating the innovative spirit and practical ability and improving their human qualities and scientific quality.

\section{Establishing a Reasonable Evaluation Mechanism and an Effective Incentive Mechanism}

It is necessary to establish a reasonable evaluation mechanism and an effective incentive mechanism for providing a good external environment for undergraduates' scientific research and innovation ability[4]. The evaluation of the students' scientific 
research and innovation activities should avoid the tendency of neglecting the process only in view of the results and be viewed in a comprehensive way, according to students' specific performance in the course of the activities. Universities could set up scholarships for scientific research, special funds for students' scientific research and special publications for them to publish papers. Meanwhile, the establishment of innovative credit system is also a very effective incentive mechanism.

\section{Stabilizing the Teaching Staff Team}

Stabilizing the Teaching Staff Team and strengthening the teachers' training work is the core of professional development and the guarantee of teaching quality, which plays an important role in the teaching, scientific research and teaching management. In view of the current situation of limited English teachers resources and relatively more young teachers, it is suggested to adopt multi-form and multi-channel teacher training methods. So building a sufficient, reasonable structured and high-level faculty could provide a solid foundation and personnel protection for cultivating undergraduate scientific research and innovation ability.

\section{Conclusion}

Emphasizing the cultivation of business English graduates scientific research ability is one of the most important means to realize the goal of cultivating business English special talents who are of high level, high standard, high quality, compound and featured. It is supposed to be a common pursuit for every foreign language educator.

\section{Acknowledgement}

This research was financially supported by philosophy and Social Sciences Research Program of Heilongjiang Province: "Research on the Model of the Feature of Business English "Triadic Reciprocal" Discipline (Ref: 16YYD11)" and "A Study on Ecological Module of Business English Talents Developing in Heilongjiang Province" (Ref.: 15EDB01).

\section{References}

[1] The State Council of the People's Republic of China. Outline of Medium - and Long - term National Science and Technology Development Plan (2006-2020). Information on http://www.gov.cn /jrzg /2006-02 /09/content_183787.htm

[2] Qi An, Cultivation Mode of Scientific Research Abilities of American Undergraduates and Construction of English Majors in China, J. Heilongjiang Researches on Higher Education, 6(2009) 68-71.

[3] Genshun Wang, Hui Wang, Ways and Practice of Cultivating Scientific Research Ability of Undergraduates in Research-oriented Universities in China, J. Research On Education Tsinghua University. 3(2008) 44-48.

[4] Ling Feng, Wei Zhang, Research on Evaluation Mechanism of Undergraduates' Scientific Research Ability, J. Heilongjiang: Higher Educational Research and Evaluation. Z1 (2008) 